\title{
Teknik yang paling dominan pada pertandingan futsal putra profesional
}

\author{
I Dewa Made Aryananda Wijaya Kusuma \\ Program Studi Pendidikan Kepelatihan Olahraga, Fakultas Ilmu Olahraga, Universitas Negeri \\ Surabaya. Jalan Rektor Unesa, Lakarsantri, Surabaya, Jawa Timur, 60213, Indonesia. \\ * Korespondensi Penulis. E-mail: dewawijaya@unesa.ac.id
}

Received: May 18, 2020 ; Revised: November 25, 2020 ; Accepted: Januari 21, 2021

\begin{abstract}
Abstrak: Penelitian ini bertujuan untuk mengetahui teknik yang paling dominan digunakan pada pertandingan futsal putra profesional. Penelitian ini termasuk pada jenis kuantitatif dengan metode survei. Sampel yang digunakan berjumlah empat tim liga futsal putra profesional dengan teknik pengambilan sampel yang digunakan adalah purposive sampling. Analisis data menggunakan uji frekuensi dan presentase dari teknik yang paling sering digunakan. Hasil dari penelitian ini menunjukkan bahwa frekuensi penggunaan teknik passing sebanyak 2181 kali, control sebanyak 1853 kali, dribbling sebanyak 422 kali, shooting sebanyak 238 kali, feinting sebanyak 92 kali, heading sebanyak 25 kali, shielding sebanyak 56 kali, turning sebanyak 17 kali, dan chipping sebanyak 37 kali. Sedangkan presentase penggunaan teknik passing sebesar 44\%, control sebesar 37\%, dribbling sebesar 9\%, shooting sebesar 5\%, feinting sebesar $2 \%$, heading sebesar $1 \%$, shielding sebesar $1 \%$, turning sebesar $0 \%$, dan chipping sebesar $1 \%$. Berdasarkan hasil tersebut dapat disimpulkan bahwa terdapat dua teknik yang sangat dominan dalam pertandingan futsal putra professional yaitu teknik passing dan control.
\end{abstract}

Kata Kunci: teknik, dominan, futsal, putra, professional.

\section{The most dominant technique in professional men's futsal matches}

\begin{abstract}
This study discusses the most dominant technique used in professional men's futsal matches. This research is a quantitative type with survey method. The sample used took four professional men's futsal league teams with the sampling technique used was purposive sampling. Data analysis uses frequency test and percentage of the most frequently used techniques. The results of this study resulted in passing 2181 times, control 1853 times, dribbling 422 times, shooting 238 times, feinting 92 times, heading 25 times, shielding 56 times, turning 17 times, and chipping 37. While the percentage of the use of passing techniques by $44 \%$, control by $37 \%$, dribbling by $9 \%$, shooting by $5 \%$, feinting by $2 \%$, heading by $1 \%$, shielding by $1 \%$, turning by $0 \%$, and chipping by $1 \%$. Based on these results it can be concluded that there are two techniques that are very dominant in professional men's futsal matches, namely passing and control techniques.
\end{abstract}

Keywords: technique, dominant, futsal, men's, professional

How to Cite: Kusuma, I D. M. A. W. (2021). Teknik yang paling dominan pada pertandingan futsal putra profesional. Jurnal Keolahragaan, 9(1), 18-25. doi: https://doi.org/10.21831/jk.v9i1.31853

\section{PENDAHULUAN}

Futsal merupakan cabang olahraga yang banyak digemari oleh masyarakat pada era saat ini. Hal ini dapat dibuktikan dengan hampir setiap daerah terdapat lapangan futsal baik yang sesuai standar maupun tidak. Ketersediaan sarana tersebut, secara tidak langsung dapat menjadi salah satu pilihan bagi masyarakat untuk sekedar mengisi waktu luang dengan bermain futsal. Selain untuk mengisi waktu luang, tidak sedikit masyarakat yang menggunakan olahraga futsal sebagai tujuan prestasi. Olahraga prestasi merupakan olahraga yang sangat terprogram serta memiliki target-target tertentu dalam hal pencapaian puncak prestasi (Kusuma, 2019). Meskipun olahraga futsal belum sepopuler sepak bola, akan tetapi dalam hal kompetisi maupun turnamen, futsal tidak kalah dengan sepakbola. Terbukti banyak event yang telah terselenggara, baik pada level amatir hingga lavel profesional seperti turnamen antar sekolah, turnamen askot, porprov, prapon, PON, liga futsal nusantara, dan liga futsal 
professional. Untuk dapat mencapai prestasi pada level tersebut, tentunya membutuhkan proses pembinaan yang panjang dan berkesinambungan. Hal tersebut menjadi suatu peluang bagi akademi ataupun les futsal untuk menawarkan program pembinaan mereka kepada masyarakat yang ingin mengarahkan putra atau putrinya kearah prestasi.

Berbicara pembinaan untuk meraih prestasi pada cabang olahraga futsal, terdapat banyak faktor yang harus dikuasai oleh seorang atlet seperti; teknik, fisik, taktik, dan mental. Hal tersebut sejalan dengan pendapat (Sukadianto, 2011) yang mengatakan bahwa faktor fisik, teknik, taktik, psikis dan sosiologis merupakan salah satu penunjang pencapaian prestasi seorang atlet. Faktor tersebut idealnya harus dimiliki oleh seorang pemain ketika ingin mencapai prestasi maksimal. Pencapaian prestasi dalam olahraga tidaklah semudah membalikkan telapak tangan, akan tetapi diperlukan waktu yang relative panjang, bertahap, dan berkesinambungan serta dalam proses pembinaannya disertai IPTEK olahraga secara sistematis (Wijono, 2011). Untuk itu, pembinaan harus dimulai sejak usia dini.Berdasarkan pemaparan para ahli diatas, penguasaan teknik merupakan salah satu faktor penting dalam pencapaian prestasi. Teknik merupakan salah satu faktor penting dalam pencapaian prestasi. Teknik harus diberikan paling awal sebelum faktor lainnya, karena teknik merupakan kemampuan dasar yang menunjang seorang atlet dalam suatu pertandingan. Teknik harus diberikan paling awal sebelum faktor lainnya, karena teknik merupakan kemampuan dasar yang menunjang seorang atlet dalam suatu pertandingan. Hal tersebut berlaku pada seluruh cabang olahraga tidak terkecuali futsal. Seorang atlet futsal harus menguasai teknik dasar futsal, teknik tersebut merupakan teknik yang mendukung ritme untuk menciptakan permainan yang baik dan merupakan salah satu faktor yang dapat memenangkan permainan (Prastyo, Sugiyanto, \& Doewes, 2017). Terdapat beberapa teknik yang harus dimiliki oleh seorang pemain futsal diantaranya; Teknik dasar futsal meliputi passing, chipping, receiving, dribbling, shooting, dan heading (Irawan, 2009). Menurut Lhaksana (2011), futsal memiliki 5 teknik dasar yaitu passing, control, chipping, dribbling, dan shooting. Menurut Mulyono (2017), teknik dasar futsal terdiri dari passing, control, chipping, dribbling, shooting, tendangan ujung kaki, heading, teknik menangkap bola dan melempar bola. Sedangkan menurut Mashud, Hamid, \& Abdillah (2019), teknik dasar futsal terdiri dari passing, control, dribbling, chipping, dan shooting.

Program latihan yang baik haruslah mencerminkan situasi pertandingan yang sebenarnya, baik kebutuhan fisik, teknik, taktik, dan mental. Sehingga saat pertandingan yang sebenarnya seorang atlet dapat mengeluarkan performa maksimal yang dimiliki. Tidak terkecuali saat latihan teknik, pelatih harus melatih sesuai dengan teknik-teknik yang diperlukan saat pertandingan. Dalam menyusun suatu program latihan, harus memperhatikan prinsip spesifikasi (Sukadianto, 2011). Prinsip spesifikasi merupakan suatu prinsip yang menuntut program latihan sesuai dengan kebutuhan cabang olahraganya. Namun sayangnya belum ada penelitian yang menunjukkan proporsi yang dominan maupun tidak tentang teknik yang digunakan saat pertandingan. Sehingga banyak pelatih memberikan porsi latihan yang sama pada setiap latihan teknik. Berdasarkan hal tersebut, muncul satu pertanyaan, apakah semua teknik yang dilatih akan digunakan dengan presentase yang sama saat pertandingan atau hanya beberapa teknik saja yang digunakan oleh seorang pemain.

Penelitian tentang teknik telah dilakukan oleh (Mohammed, Shafizadeh, \& Platt, 2014) yang menemukan bahwa teknik passing, control, dan shooting merupakan teknik yang paling akurat yang dilakukan oleh pemail elit. Namun terdapat perbedaan dari hasil penelitian yang dilakukan oleh (Naser \& Ali, 2016), dalam penelitiannya menyimpulkan bahwa teknik yang paling superior dilakukan oleh elit pemain adalah passing dan shooting. Hal ini menjadi menarik, apakah hasil penelitian tersebut dapat diterapkan pada pemain Indonesia yang memiliki karakteristik cepat dan memiliki posture tubuh relative tidak setinggi pemain eropa.

Urgensi yang pertama dari penelitian ini adalah belum adanya penelitian yang membahas tentang presentase kebutuhan teknik yang dominan saat pertandingan, sebagian besar penelitian hanya sebatas bagaimana metode melatih, model latihan, dan statistic pertandingan seperti artikel yang diteliti oleh Eka \& Darmawan (2014) berjudul "metode pelatihan taktis passing berpasangan statis dan passing sambil bergerak terhadap teknik dasar passing control bola futsal", artikel yang diteliti oleh (Fitranto \& Budiawan, 2019) berjudul "analisis menyerang timnas futsal putri Indonesia pada final AFF woman futsal championship 2018", artikel yang ditulis oleh (Sari, Sidik, \& Komarudin, 2019) berjudul "the application of high intensity interval training (HIIT) method to icrease of aerobic ability of female futsal player", artikel yang ditulis oleh (Méndez-Domínguez, Gómez-Ruano, Rúiz-Pérez, \& Travassos, 2019) yang berjudul "Goals scored and received in 5vs4 GK game strategy are constrained 
by critical moment and situational variables in elite futsal'. Urgensi yang kedua yaitu perlu adanya pembagian teknik yang dominan dan tidak dalam permainan. Urgensi yang ketiga, dengan adanya data tentang teknik dominan yang harus dimiliki oleh seorang pemain, maka akan mempermudah pelatih dalam memfokuskan materi program latihan teknik.

Untuk menjawab urgensi diatas, maka diperlukan penelitian tentang presentase dominan teknik dasar yang digunakan saat pertandingan. Diharapkan setelah mengetahui presentase tersebut, akan dapat membantu para pelatih dalam membuat program latihan yang efisien dan terfokus pada kebutuhan pertandingan.

\section{METODE}

Penelitian ini menggunakan metode deskriptif kuantitatif. Metode deskriptif merupakan metode penelitian yang bertujuan untuk mendeskripsikan atau menggambarkan secara sistematik fakta dengan akurat tentang gejala (phenomena) tertentu yang menjadi pusat perhatian peneliti (Mahardika, 2015). Penelitian kuantitatif merupakan penelitian yang menggunakan angka mulai dari pengumpulan data, penafsiran, serta penampilan data tersebut (Suharsimi, 2013).

Pengambilan data dilakukan dengan metode observasi pada saat pertandingan final four liga futsal putra profesional tahun 2019 di GOR UNY Yogyakarta. Teknik pengambilan sampel menggunakan teknik purposive sampling. Teknik purposive sampling menghendaki pengambilan sampel dengan tujuan-tujuan tertentu yang dideskripsikan sesuai dengan keperluan penelitian (Mahardika, 2015). Adapun tujuan penelitian ini yaitu mengambil data pada empat tim terbaik yang berlaga pada semifinal liga futsal professional 2019. Empat tim tersebut yaitu; BTS, VM, BSM, SKN.

Instrumen pengambilan data menggunakan table check list jumlah teknik dasar yang muncul pada setiap pertandingan, teknik yang terdapat pada tabel tersebut yaitu; passing, control, dribbling, feinting, shielding, turning, shooting, chipping, dan heading. Data yang didapat dianalisis menggunakan nilai presentase. Formula yang digunakan untuk mencari presentase (Sugiyono, 2016) adalah: $P=\frac{f}{N}(\mathrm{P}:$ Presentase; $\mathrm{F}:$ Frekuensi; $\mathrm{N}:$ Jumlah Responden $)$

\section{HASIL DAN PEMBAHASAN}

Data yang dihasilkan dalam penelitian ini berupa frekuensi dan presentase teknik yang muncul dalam suatu pertandingan. Data tersaji dalam gambar dibawah ini :

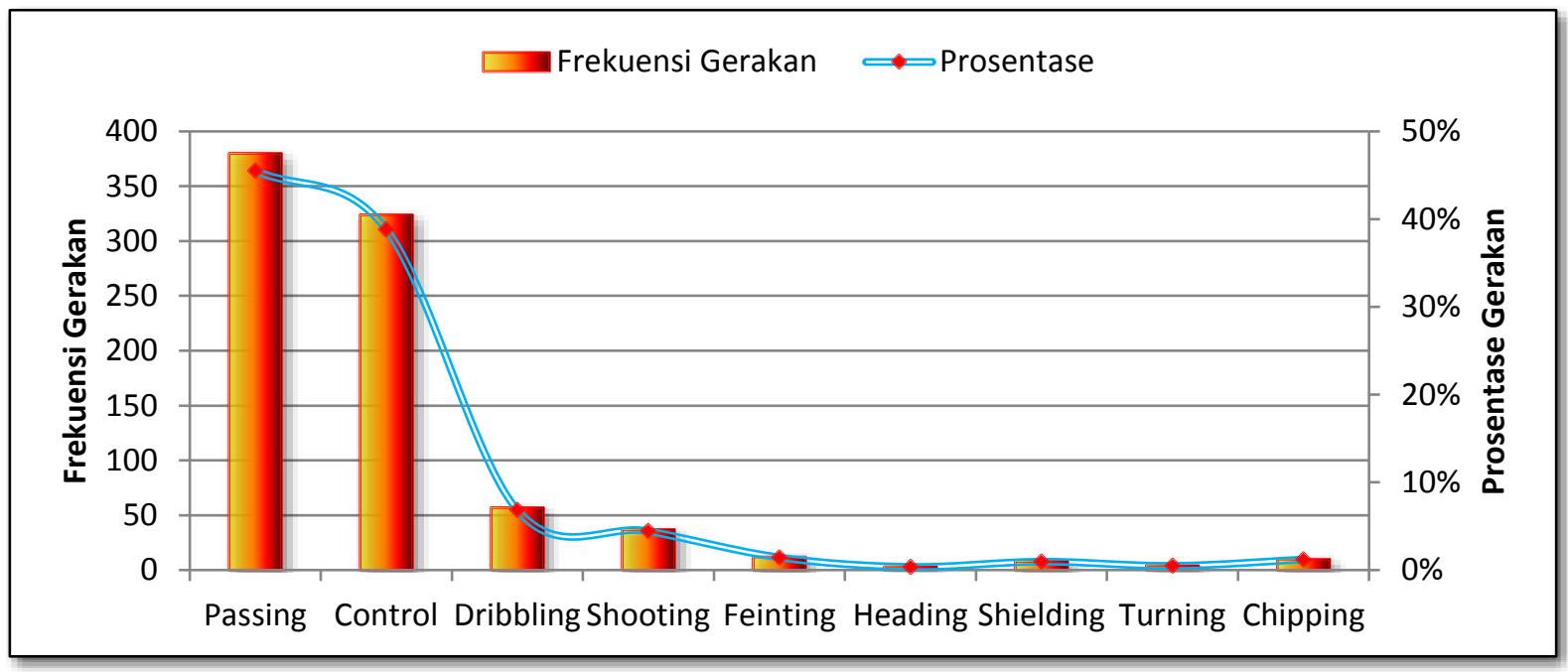

Gambar 1. Frekuensi dan prosentase teknik BTS

Data di atas (Gambar 1) merupakan hasil analisis teknik yang digunakan oleh seluruh pemain tim BTS pada semifinal melawan tim VM, adapun frekuensi teknik yang digunakan sebagai berikut; passing sebanyak 380 kali, control sebanyak 324 kali, dribbling sebanyak 57 kali, shooting sebanyak 37 kali, feinting sebanyak 12 kali, heading sebanyak 3 kali, shielding sebanyak 8 kali, turning sebanyak 4 kali, dan chipping sebanyak 10 kali. Apabila dilihat dari segi presentase maka hasil data adalah sebagai berikut; passing sebesar 46\%, control sebesar 39\%, dribbling sebesar 7\%, shooting 
Jurnal Keolahragaan 9 (1), 2021 - 21

I Dewa Made Aryananda Wijaya Kusuma

sebesar 4\%, feinting sebesar 1\%, heading sebesar 0\%, shielding sebesar $1 \%$, turning sebesar $0 \%$, dan chipping sebesar $1 \%$.

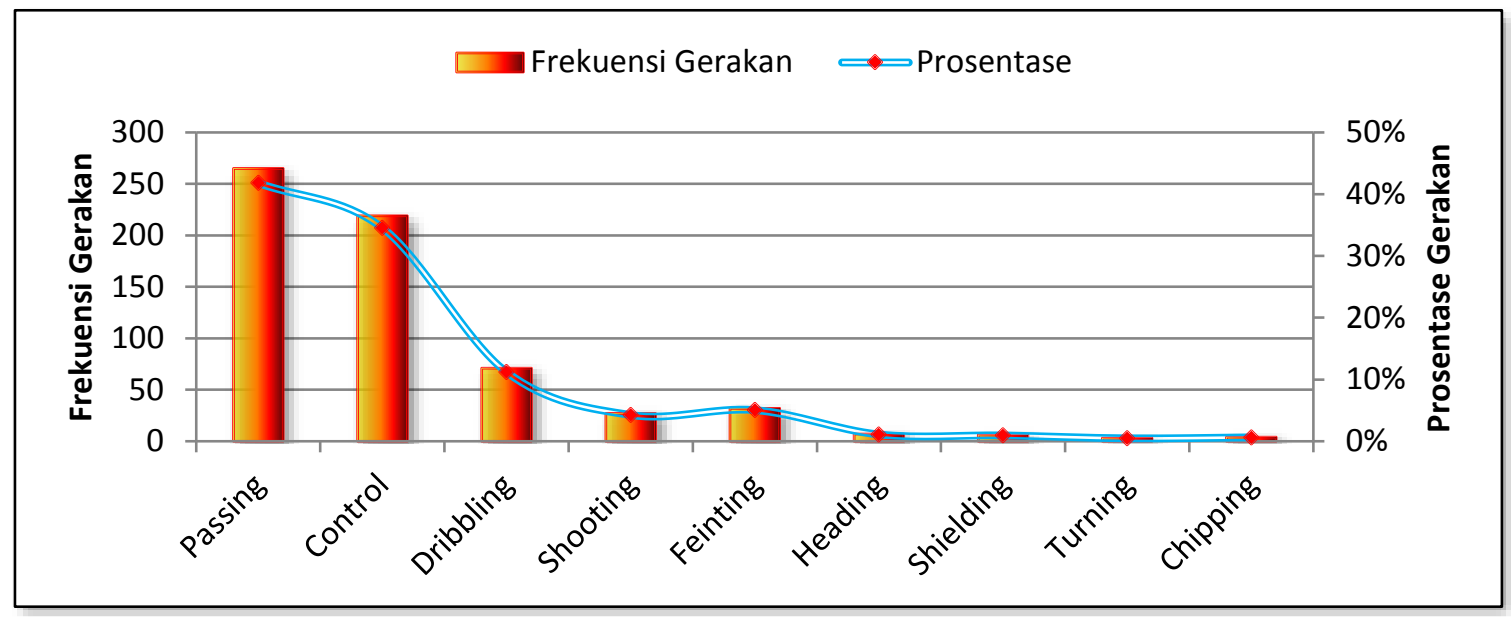

Gambar 2. Frekuensi dan prosentase teknik VM

Selain itu, hasil analisis teknik pada Gambar 2. yang digunakan oleh seluruh pemain tim VM pada semifinal melawan tim BTS, adapun frekuensi teknik yang digunakan sebagai berikut; passing sebanyak 265 kali, control sebanyak 219 kali, dribbling sebanyak 71 kali, shooting sebanyak 27 kali, feinting sebanyak 32 kali, heading sebanyak 7 kali, shielding sebanyak 6 kali, turning sebanyak 3 kali, dan chipping sebanyak 4 kali. Apabila dilihat dari segi presentase maka hasil data adalah sebagai berikut; passing sebesar 42\%, control sebesar 35\%, dribbling sebesar 11\%, shooting sebesar 4\%, feinting sebesar 5\%, heading sebesar 1\%, shielding sebesar 1\%, turning sebesar 0\%, dan chipping sebesar $1 \%$.

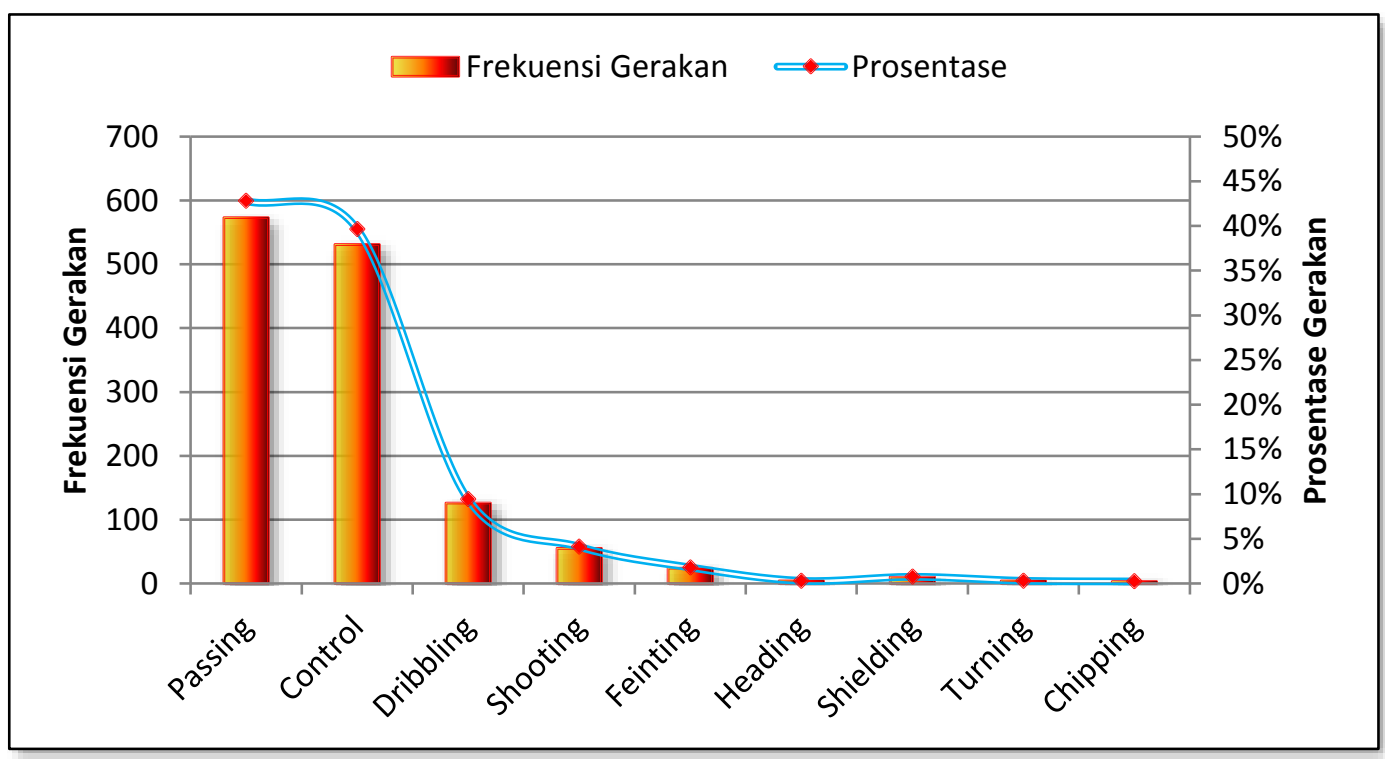

Gambar 3. Frekuensi dan prosentase teknik BSM

Hasil analisis teknik yang digunakan oleh seluruh pemain tim BSM pada semifinal melawan tim SKN (Gambar 3), adapun frekuensi teknik yang digunakan sebagai berikut; passing sebanyak 573 kali, control sebanyak 531 kali, dribbling sebanyak 126 kali, shooting sebanyak 55 kali, feinting sebanyak 24 kali, heading sebanyak 4 kali, shielding sebanyak 10 kali, turning sebanyak 4 kali, dan chipping sebanyak 3 kali. Apabila dilihat dari segi presentase maka hasil data adalah sebagai berikut; passing sebesar 43\%, control sebesar 40\%, dribbling sebesar 9\%, shooting sebesar 4\%, feinting sebesar $2 \%$, heading sebesar $0 \%$, shielding sebesar 1\%, turning sebesar 0\%, dan chipping sebesar $0 \%$. 
Jurnal Keolahragaan 9 (1), 2021 - 22

I Dewa Made Aryananda Wijaya Kusuma

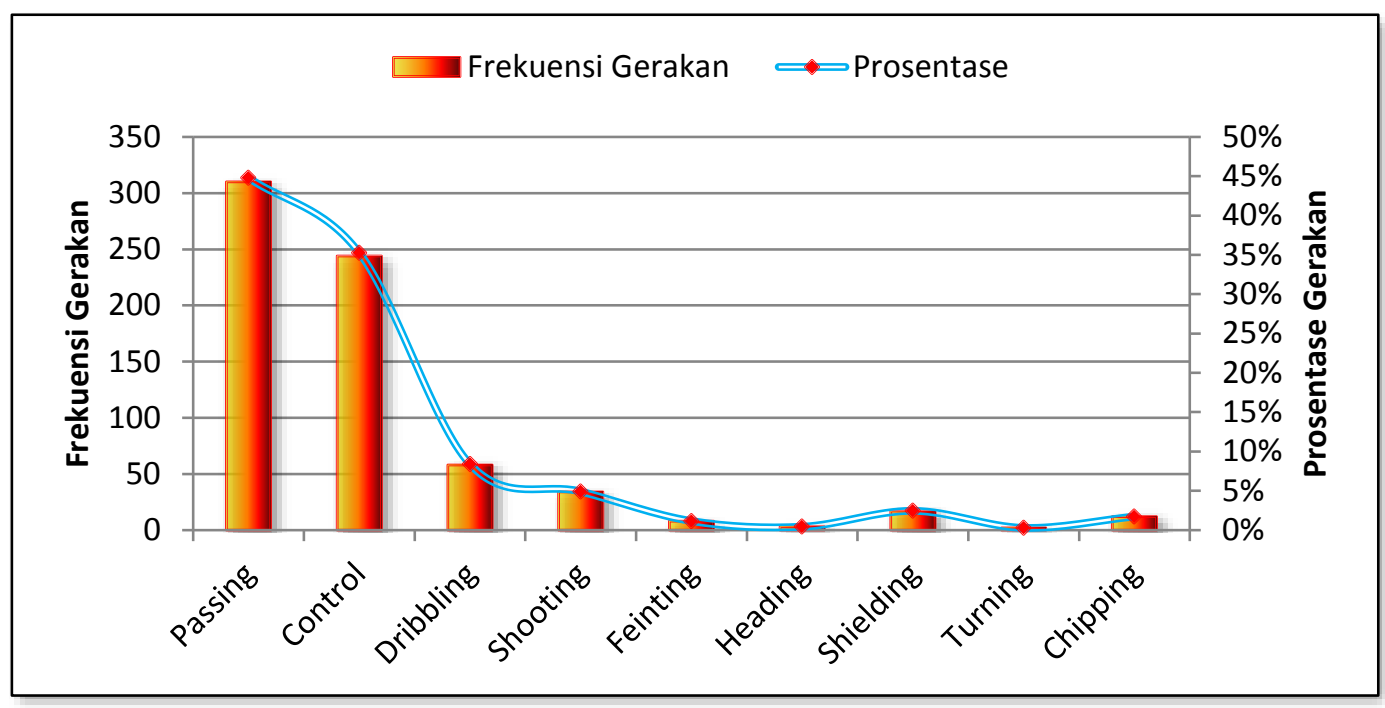

Gambar 4. Frekuensi dan prosentase teknik SKN

Sementara, hasil analisis teknik yang digunakan oleh seluruh pemain tim SKN pada semifinal melawan tim BSM terdapat pada Gambar 4., adapun frekuensi teknik yang digunakan sebagai berikut; passing sebanyak 310 kali, control sebanyak 244 kali, dribbling sebanyak 58 kali, shooting sebanyak 34 kali, feinting sebanyak 8 kali, heading sebanyak 3 kali, shielding sebanyak 17 kali, turning sebanyak 2 kali, dan chipping sebanyak 12 kali. Apabila dilihat dari segi presentase maka hasil data adalah sebagai berikut; passing sebesar $45 \%$, control sebesar 35\%, dribbling sebesar $8 \%$, shooting sebesar 5\%, feinting sebesar 1\%, heading sebesar 0\%, shielding sebesar 2\%, turning sebesar 0\%, dan chipping sebesar $2 \%$.

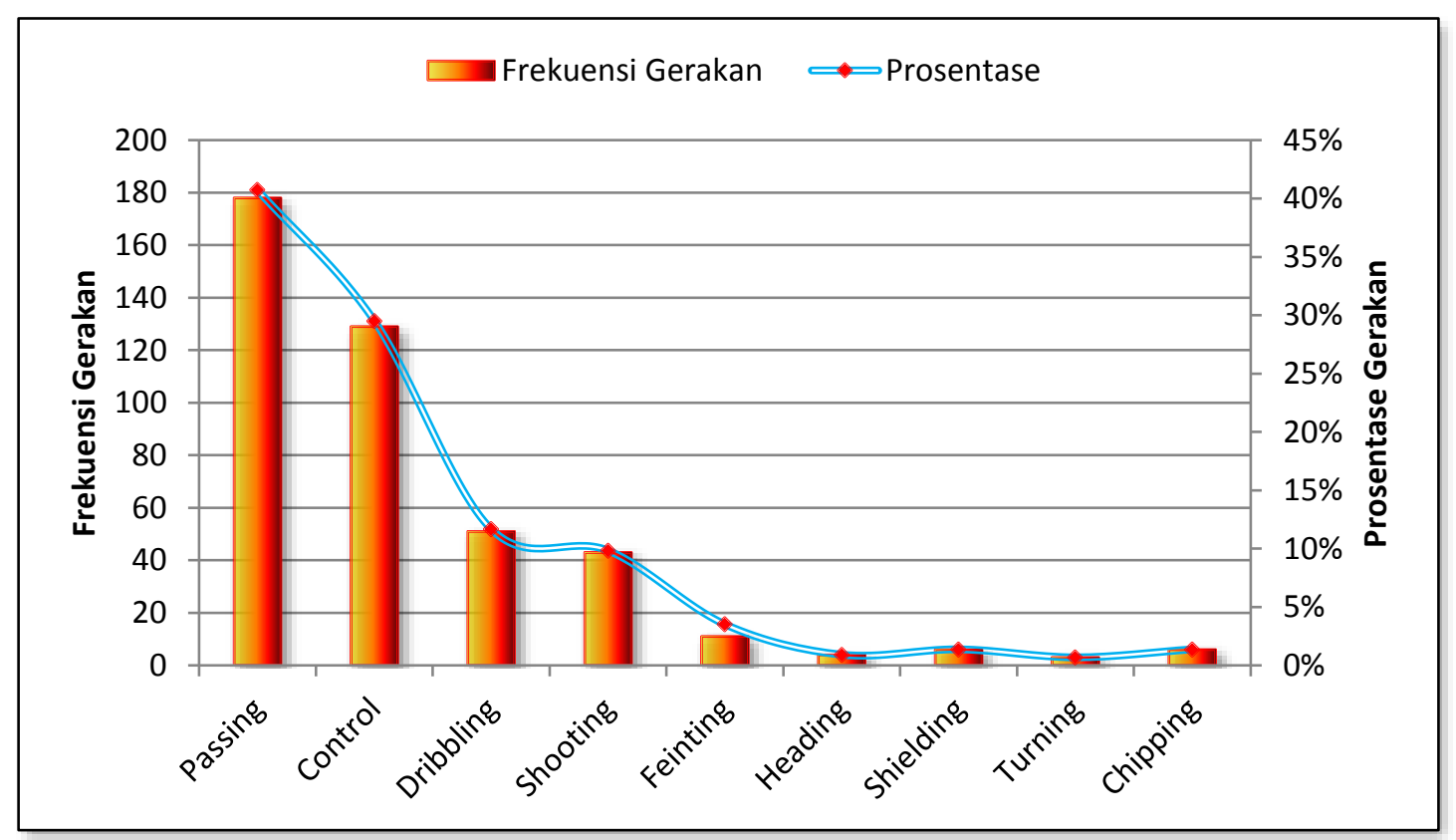

Gambar 5. Frekuensi dan prosentase teknik VM

Pada Gambar 5., terlihat hasil analisis teknik yang digunakan oleh seluruh pemain tim VM pada pertandingan final melawan tim BSM, adapun frekuensi teknik yang digunakan sebagai berikut; passing sebanyak 178 kali, control sebanyak 129 kali, dribbling sebanyak 51 kali, shooting sebanyak 43 kali, feinting sebanyak 11 kali, heading sebanyak 4 kali, shielding sebanyak 6 kali, turning sebanyak 3 kali, dan chipping sebanyak 6 kali. Apabila dilihat dari segi presentase maka hasil data adalah sebagai berikut; passing sebesar $41 \%$, control sebesar 30\%, dribbling sebesar 12\%, shooting 
Jurnal Keolahragaan 9 (1), 2021 - 23

I Dewa Made Aryananda Wijaya Kusuma

sebesar $10 \%$, feinting sebesar $4 \%$, heading sebesar $1 \%$, shielding sebesar $1 \%$, turning sebesar $1 \%$, dan chipping sebesar $1 \%$.

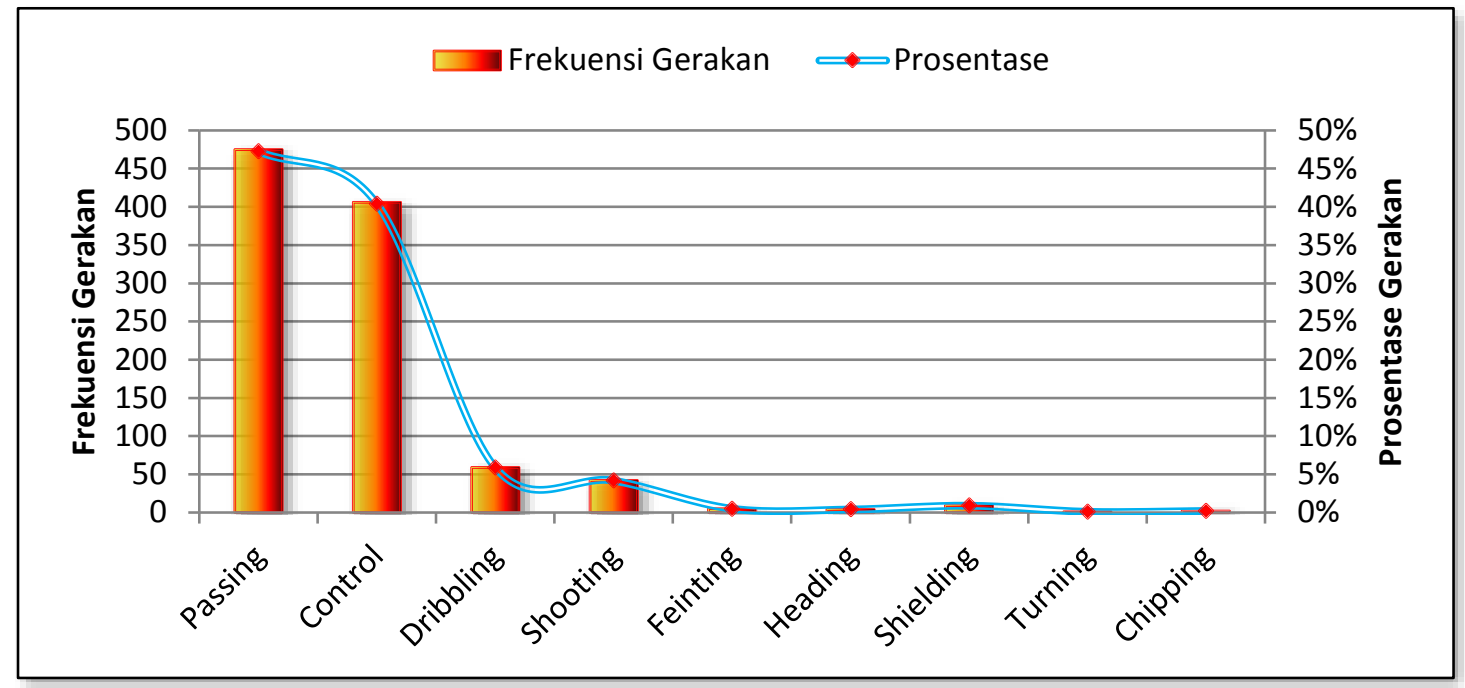

Gambar 6. Frekuensi dan prosentase teknik BSM

Hasil analisis teknik yang digunakan oleh seluruh pemain tim BSM pada pertandingan final melawan tim VM terdapat pada Gambar 6., adapun frekuensi teknik yang digunakan sebagai berikut; passing sebanyak 475 kali, control sebanyak 406 kali, dribbling sebanyak 59 kali, shooting sebanyak 42 kali, feinting sebanyak 5 kali, heading sebanyak 4 kali, shielding sebanyak 9 kali, turning sebanyak 1 kali, dan chipping sebanyak 2 kali. Apabila dilihat dari segi presentase maka hasil data adalah sebagai berikut; passing sebesar 47\%, control sebesar 40\%, dribbling sebesar 6\%, shooting sebesar $4 \%$, feinting sebesar $0 \%$, heading sebesar $0 \%$, shielding sebesar $1 \%$, turning sebesar $0 \%$, dan chipping sebesar $0 \%$.

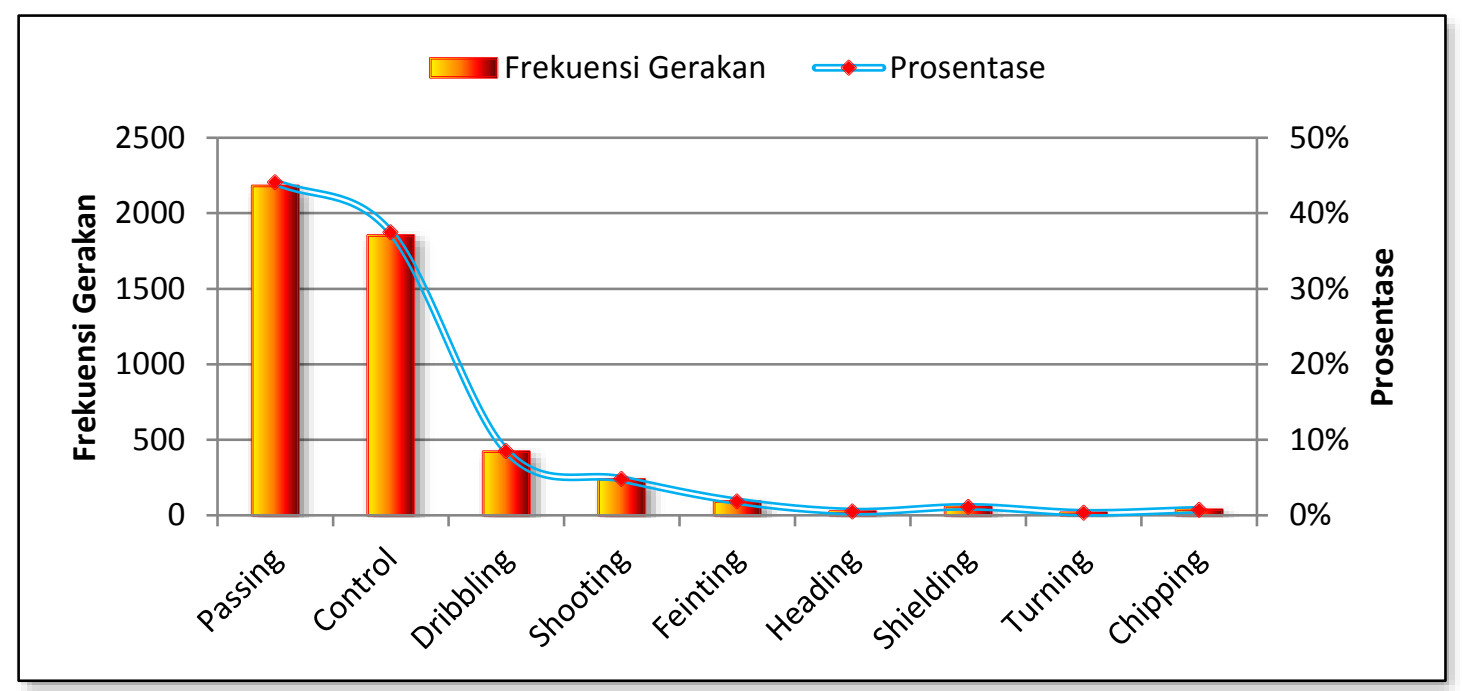

Gambar 7. Frekuensi dan prosentase teknik keseluruhan tim

Hasil keseluruhan analisis teknik (Gambar 7) yang digunakan oleh seluruh tim yang berlaga pada final four liga futsal professional 2019, adapun frekuensi teknik yang digunakan sebagai berikut; passing sebanyak 2181 kali, control sebanyak 1853 kali, dribbling sebanyak 422 kali, shooting sebanyak 238 kali, feinting sebanyak 92 kali, heading sebanyak 25 kali, shielding sebanyak 56 kali, turning sebanyak 17 kali, dan chipping sebanyak 37 kali. Apabila dilihat dari segi presentase maka hasil data adalah sebagai berikut; passing sebesar 44\%, control sebesar 37\%, dribbling sebesar 9\%, 
shooting sebesar 5\%, feinting sebesar 2\%, heading sebesar $1 \%$, shielding sebesar $1 \%$, turning sebesar $0 \%$, dan chipping sebesar $1 \%$.

Berdasarkan analisis data yang dilakukan diatas, berikut ini merupakan urutan teknik dasar yang paling sering digunakan sampai yang paling jarang digunakan, yaitu; passing, control, dribbling, shooting, feinting, shielding, heading, chipping, dan turning. Apabila ditinjau dari segi kuantitas, maka teknik passing dan control menduduki peringkat yang tertinggi yang paling sering digunakan dibandingkan dengan teknik lainnya. Futsal merupakan permainan yang dimainkan dengan intensitas yang tinggi, dengan kecepatan dan membutuhkan pengambilan keputusan yang cepat dan efisien (Kusuma, 2019), sehingga untuk dapat bermain dengan cepat dibutuhkan alur bola yang cepat dan akurat, tentunya teknik passing dan control sangat menunjang dalam hal tersebut. Seluruh pemain termasuk kipper dituntut harus memiliki kualitas passing dan control yang baik. Selain bermain secara normal, teknik passing dan control sangat dibutuhkan pada strategi powerplay. Powerplay merupakan salah satu strategi untuk mencetak gol dimana seorang kipper membantu penyerangan sampai kedaerah pertahanan lawan. Dalam bermain powerplay, diperlukan alur bola yang cepat untuk membongkar pertahanan lawan. Dalam penelitian ini, teknik dribble, shooting, feinting, shielding, heading, chipping, dan turning mendapatkan presentasi sangat kecil yaitu dibawah 9\%. Menurut peneliti, teknik dribble tidak terlalu digunakan saat pertandingan, mengingat ukuran lapangan yang kecil menyulitkan seorang pemain untuk melakukan dribble dalam permainan. Hal tersebut sejalan dengan pendapat (Corrêa et al., 2016), dalam penelitiannya menyimpulkan bahwa keberhasilan teknik dribbling dipengaruhi oleh jarak dan zona pemain dilapangan. Sehingga dapat disimpulkan bahwa didalam permainan futsal yang ukuran lapangannya kecil sangat menyulitkan untuk melakukan teknik dribbling. Namun demikian teknik dribble tetap dibutuhkan saat melakukan counter attack cepat. Teknik shooting sebenarnya sangat penting dalam suatu pertandingan. Menurut (Mulyono, 2017) teknik shooting digunakan untuk mencetak gol dalam permainan futsal. Selain itu menurut (Hidayat \& Rusdiana, 2018) menyatakan bahwa teknik shooting sangat penting dimiliki oleh setiap pemain. Namun demikian berdasarkan analisis data yang didapatkan teknik shooting jarang dilakukan dalam permainan, pemain lebih sering mengarahkan mengarahkan ke tiang kedua untuk menciptakan gol, sehingga tidak diperlukan teknik shooting yang keras. Menurut (Lhaksana, 2011) teknik feinting merupakan teknik yang digunakan untuk menipu lawan dengan gerakan yang berubah arah. Berdasarkan hasil data, teknik ini sangat jarang dilakukan karena membutuhkan kecepatan dan koordinasi kaki diatas rata-rata serta kemungkinan gagal melewati lawan sangatkah tinggi. Teknik shielding, heading, chipping, dan turning mendapatkan presentase yang paling sedikit digunakan saat pertandingan. Hal tersebut disebabkan karena teknik digunakan pada situasi tertentu saja, seperti; pemain pivot saat melindungi bola menggunakan shielding untuk menunggu support serta menggunakan turning untuk memutar badan saat tidak ada support dari teman. Pemain ancor menghalau bola atas dengan menggunakan teknik heading. Yang terakhir adalah teknik chipping yaitu mencungkil bola untuk melewati lawan. Menurut (Mulyono, 2017) teknik chipping biasa digunakan oleh tim yag mengusung strategi long-ball. Meskipun teknik tersebut sangat jarang dilakukan oleh pemain, namun harus tetap dilatih untuk menghadapi situasi yang menuntut teknik tersebut digunakan

\section{SIMPULAN}

Terdapat dua teknik yang paling dominan dalam pertandingan yaitu passing dan control sedangkan teknik yang lain tetap dibutuhkan pada situasi tertentu. Untuk penelitian selanjutnya diharapkan dapat meneliti lebih dalam lagi terkait kebutuhan teknik tiap individu dan tiap posisi sehingga diharapkan tercipta suatu pedoman kebutuhan teknik berdasarkan kebutuhan pemain tiap posisi.

\section{DAFTAR PUSTAKA}

Corrêa, U. C., de Pinho, S. T., da Silva, S. L., Clavijo, F. A. R., Souza, T. de O., \& Tani, G. (2016). Revealing the decision-making of dribbling in the sport of futsal. Journal of Sports Sciences. https://doi.org/10.1080/02640414.2016.1232488

Eka, G., \& Darmawan, B. (2014). Metode Pelatihan Taktis Passing Berpasangan Statis Dan Passing Sambil Bergerak Terhadap Keterampilan Teknik Dasar Passing Control Bola Futsal. E-Journal $P K O$. 
Fitranto, N., \& Budiawan, R. (2019). ANALISIS MENYERANG TIMNAS FUTSAL PUTRI INDONESIA PADA PIALA AFF WOMEN FUTSAL CHAMPHIONSHIP TAHUN 2018. Ilmiah Sport Coaching And Education Vol. 1.

Hidayat, I., \& Rusdiana, A. (2018). ANALISIS BIOMEKANIK TENDANGAN SHOOTING PADA ATLET FUTSAL PUTRA UKM FUTSAL UNIVERSITAS PENDIDIKAN INDONESIA. Jurnal Sains Keolahragaan Dan Kesehatan. https://doi.org/10.5614/jskk.2018.3.2.3

Irawan, A. (2009). Teknik Dasar Modern Futsal. Jakarta: Pena Pundi Aksara.

Kusuma, I. D. M. A. W. (2019). The influence of the differences within the preliminary vo2max level on the Tabata training results. Jurnal SPORTIF : Jurnal Penelitian Pembelajaran. https://doi.org/10.29407/js_unpgri.v5i2.13490

Lhaksana, J. (2011). Taktik dan Strategi Futsal Modern. Jakarta: BE CHAMPION.

Mahardika, I. M. S. (2015). Metodologi Penelitian. Surabaya: Unesa University Press.

Mashud, M., Hamid, A., \& Abdillah, S. (2019). PENGARUH KOMPONEN FISIK DOMINAN OLAHRAGA FUTSAL TERHADAP TEKNIK DASAR PERMAINAN FUTSAL. Gladi : Jurnal Ilmu Keolahragaan. https://doi.org/10.21009/gjik.101.04

Méndez-Domínguez, C., Gómez-Ruano, M. A., Rúiz-Pérez, L. M., \& Travassos, B. (2019). Goals scored and received in 5vs4 GK game strategy are constrained by critical moment and situational variables in elite futsal. Journal of Sports Sciences. https://doi.org/10.1080/02640414.2019.1640567

Mohammed, A., Shafizadeh, M., \& Platt, G. K. (2014). Effects of the level of expertise on the physical and technical demands in futsal. International Journal of Performance Analysis in Sport. https://doi.org/10.1080/24748668.2014.11868736

Mulyono, M. A. (2017). Buku Pintar Futsal. Jakarta: Anugrah.

Naser, N., \& Ali, A. (2016). A descriptive-comparative study of performance characteristics in futsal players of different levels. Journal of Sports Sciences. https://doi.org/10.1080/02640414.2015.1134806

Prastyo, B. W., Sugiyanto, \& Doewes, M. (2017). THE DEVELOPMENT MODEL OF THE BASIC TECHNIQUES OF EXERCISE AND PHYSICAL EXERCISE ON FUTSAL PLAYERS LEVEL INTERMEDIATE. European Journal of Physical Education and Sport Science, 2(3), 50-58. https://doi.org/10.5281/zenodo.376857

Sari, Y., Sidik, D. Z., \& Komarudin, K. (2019). The Application of High Intensity Interval Training (HIIT) Method to the Increase of Aerobic Ability of Female Futsal Players. https://doi.org/10.2991/icsshpe-18.2019.6

Sugiyono, P. D. metode penelitian kuantitatif, kualitatif,dan R\&D., Alfabeta, cv. (2016).

Suharsimi, A. (2013). Prosedur Penelitian : Suatu Pendekatan Praktik (Edisi Revisi). Jakarta: Rineka Cipta. https://doi.org/10.1017/CBO9781107415324.004

Sukadianto. (2011). Pengantar Teori dan Metodologi Melatih Fisik. Bandung: CV. Lubuk Agung.

Wijono. (2011). Pemanfaatan IPTEK Olahraga Dalam Peningkatan Prestasi. Kepelatihan Olahraga. 